\section{NSF gets new director}

Almost as soon as John B. Slaughter, the outgoing director of the US National Science Foundation (NSF), the nation's basic research agency, announced that he would leave on 1 November to take up his duties at the University of Maryland, the White House announced his successor. On 3 November Edward A. Knapp assumed his new duties as director.

Knapp, a physicist with degrees from Pomona College and the University of California at Berkeley, had been confirmed in September as assistant director of NSF for mathematical and physical sciences. His entire previous career was with the Los Alamos National Laboratory, where he worked with George A. Keyworth, who is now the President's Science Advisor. Ironically, the White House personnel office made the appointment with despatch while Keyworth, Slaughter and NSF's deputy director Donald Langenberg - who was rumoured as a likely candidate - were out of town.

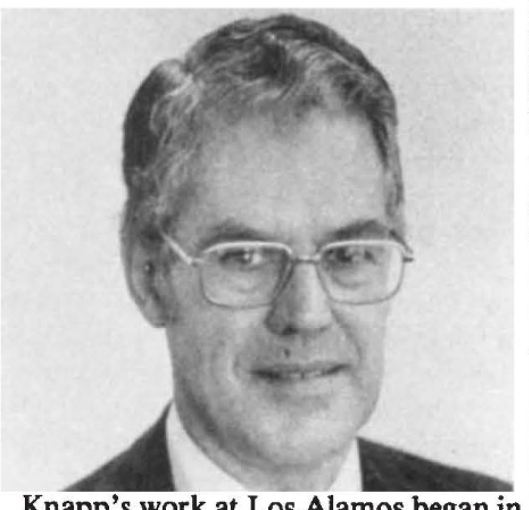

Knapp's work at Los Alamos began in 1958. He worked on controlled thermonuclear research and helped to plan the linear proton accelerator, the Los Alamos Meson Physics Facility (LAMPF). Knapp spent a year at CERN in Geneva, where he worked out a collaborative programme between CERN and Los Alamos. Before coming to Washington Knapp was director of the laboratory's accelerator technology division.

Since Congress is in recess at present, Knapp is assuming his duties without being formally confirmed. Langenberg plans to stay on, although his name is on a list of candidates for the presidency of the University of New Mexico. At the time that Knapp was appointed, there were rumours in Washington of a major conservative housecleaning at NSF, which could not be confirmed. Moreover, the national elections, which seemed to deprive the Reagan Administration of some of its far-right conservative mandate, make such a sweep very unlikely. Deborah Shapley

\title{
French energy
}

\section{Forecasts fall}

In the midst of an appalling economic crisis, the French government is about to be struck another blow with the expected publication this week of an official energy forecast which will lower projected electricity consumption in 1990 by nearly a quarter.

The consequences fall neatly on the coal and nuclear industries, both of them political hot potatoes for a socialist government. Coal and nuclear energy are the dominant power sources in France (producing 24 per cent and 37 per cent of delivered electric power in 1981), excepting hydroelectricity (27 per cent) which, as nearly "free" power, is likely to be untouched by the new forecast. The socialist party has committed itself to support the coal industry - and indeed expand production - but the nuclear lobby is strong and supported vociferously by the powerful research and industry minister, Jean-Pierre Chevènement.

The new figures come from the Commission du Plan, an institution which is both within and to some degree aside from the government. But its pronouncements - broad political and economic plans for the future - are taken seriously. In this case, the "long-term energy" committee of the commission has calculated that electricity consumption will not be 450,000 million $\mathrm{kWh}$ in 1990 as envisaged in the previous (1980) plan, but only 350,000 million $\mathrm{kWh}$, compared with a true consumption in 1980 of 246,000 million $\mathrm{kWh}$. Thus the projected increase has been halved, with a consequent revolution in thinking about power station construction and power sales.

Electricité de France (EDF), which is strongly behind nuclear power, contests the figures and predicts that consumption will be 390,000 million $\mathrm{kWh}$ in 1990 ; but it still admits that there will be overcapacity. EDF argues that surplus electricity can be exported - French electricity is the cheapest in Europe, largely because of government pricing policy - and that the nuclear power industry must build at least two stations a year until 1990 or it will collapse. A successful nuclear industry will lead to nuclear exports later, the argument goes. But if nuclear power station construction continued at the present rate of four stations a year, it is estimated that coal burning for electricity - which makes up half the French coal market - would fall from its present level of 64,000 million $\mathrm{kWh}$ to 32,000 million $\mathrm{kWh}$ in 1985 and even less in 1990

With little union backing for coal (the communist CGT union, which is strong in both the coal and nuclear industry has opted for nuclear energy), and with Chevènement behind nuclear power, it seems likely that the EDF view will be supported, and a substantial nuclear programme maintained, with unpleasant consequences for the socialist party in the French coal districts in the municipal elections in the spring.

Why then are the forecasts falling? The answer is twofold. First, French economic growth is well below target, and seems unlikely to rise before 1985; and second there is growing confidence in the Agency Française pour la Maitrise de l'Energie (AFME), which seems to have had considerable success since its formation earlier this year from a group of disparate bodies concerned with energy conservation and renewable energies.

In 1983, AFME will invest FF 1,200 million ( $£ 100$ million), much of it in investment support grants which will raise a total of FF 20,000 million ( $£ 1,300$ million) in conservation and alternatives next year. The aim is to reach FF 40,000 million $(£ 2,600$ million) a year by 1990 , comparable with the present French investment rate in nuclear power. Some of the seed money is being raised by a tax on petrol at the pump.

By 1990 , AFME is expected to have led to renewables usage of some 12 million tonnes of oil equivalent a year (around 10 per cent of primary energy consumption) with the greatest portion coming from wood and biomass, then from lowtemperature geothermal heat (particularly by better exploitation of sources in the Paris basin) and finally from solar power. But the great saving comes in energy conservation - around 40 million tonnes of oil equivalent a year by 1990 , according to AFME projections, which are broadly accepted by the Commission du Plan.

Robert Walgate

Genetic engineering

\section{Human insulin}

\section{Washington}

The commercial potential of genetic engineering was boosted in the United States on 29 October when the Food and Drug Administration (FDA) gave marketing approval to Humulin, a human insulin made with genetic engineering techniques. Made by Eli Lilly Company, the substance had won approval for marketing in the United Kingdom only a month before (see Nature 23 September, p.293). Although the announcement has symbolic value in the field and in particular for Genentech Inc., the California company that invented it, it will probably not quickly make a material difference to the fortunes of either Genentech or Eli Lilly.

Genetically-engineered human insulin is expected to be almost twice as expensive as the insulins now derived from pigs and cattle, which cost an estimated 26-30 cents per day of treatment. Lilly already has an estimated 85 per cent of the insulin market in the United States, so there is not likely to be a large market for Humulin soon, although the new product has an advantage in the few diabetics who develop an allergy 
to animal insulins.

The announcement of FDA approval had been so long expected that neither Genentech's nor Lilly's stock jumped much in response, although Lilly's stock, which has been depressed since its sudden withdrawal of the anti-arthritis drug Oraflex earlier this year, traded a little higher after the FDA announcement on Humulin.

FDA gave approval on the basis of safe performance in trials involving about 400 patients a mere five months after Lilly filed its application. The agency also has in the pipeline applications for genetically-engineered products such as human growth hormones and interferons. Approval can take as long as two years, but the agency has recently undertaken a series of controversial moves to shorten approval time and simplify procedures.

Genentech is the first of the highly competitive biotechnology companies with a product approved for human use. The company's task was enormously eased by the security of the support provided by Lilly, which has exclusive licensing rights and which is estimated to have spent $\$ 100$ million in bringing the product to market. Genentech will receive a royalty on sales which is thought to be in single figures.

Genentech may be following a riskier path in its development of human growth hormone products and gamma interferon. It plans to market these products itself, which explains why it persuaded a group of investors to buy limited partnerships in October, thereby raising $\$ 55$ million for research. This will support work on a human growth hormone product for children who suffer from dwarfism, but since these are few in number the product would also have to be useful in combating CDSS (constitutionally delayed short stature), a problem that afflicts a greater number of people. Ideally, such a product could also help patients with cachexia, a wasting syndrome.

In addition to the limited partnership, in October four Swedish organizations bought $\$ 20$ million in Genentech's outstanding shares, or 571,428 shares at $\$ 35$ per share. (Two weeks later, after the limited partnerships and the FDA announcement, the company's stock reached $\$ 50$ a share.) The four organizations are Alfa-Laval AB, the Wallenberg Foundation, AB Fannyudde, an investment company affiliated with Volvo, and D. Carengie and Co., another investment company. The president and chief executive officer of Alfa-Laval AB, Harry Faulkner, was made a member of Genentech's board of directors. The company also appointed to its board John T. Potts, chief of the Department of Medicine at the Massachusetts General Hospital. Dr David W. Martin, a professor of medicine and biochemistry at the University of California, San Francisco, has been appointed vice-president for research.

Deborah Shapley
Biotechnology index

\section{Biotechnology index beats Dow}

\section{Washington}

Nature's third monthly Biotechnology Index set a new high in October, reaching 140.2 from a base of 100 at the end of June. This increase was greater than either the Industrial Index, the leading index of US industrial trading, or the Standard \& Poor's 400 index of leading industrial stocks. Thus, the biotechnology companies moved parallel to, but ahead of, the market surge that led the Dow Jones mark in the first week of October.

But the performance of the Nature Biotechnology Index may have as much to do with internal factors in the companies themselves as with trends on Wall Street. The "Street" was reacting to continued lowering of inflation and the perception that the US elections, just held, would not upset the direction of the US economy. As one analyst in New York explained, the overall market surge was caused by "institutional money managers getting in who don't want to miss more of the rally". Such managers buy huge blocks of stock and so stay away from smaller companies recent increases in the Dow Jones index finally to break through the 1,000 where such buying would artificially drive up the price.

The analyst went on to suggest that one reason why the Nature index did so well was because two companies in the index are funds and stable enough to ride along with the trend. These are A.B. Fortia of Sweden and Novo Industri A/S of Denmark, which had market capitalizations valued at \$751 million and \$789 million respectively on 29 October, when the index was calculated. The reasons for the rise in stock price of Genetech are outlined in the preceding story.

The other small companies in the index have also done well lately. "There have been no major flubs in the group", one analyst says. For example, the stock of Cetus, in Berkeley, California, rose after the company announced lay-offs and a redirection of its research. This was seen as a net gain for the company, because specialists in biotechnology investment had felt that Cetus was over-extended. Hybritech and Damon of Needham have been getting considerable public attention for their work.

Deborah Shapley large enough to attract some institutional

Nature index of biotechnology stocks

\begin{tabular}{|c|c|c|c|c|c|}
\hline $\begin{array}{l}1982 \\
\text { high }\end{array}$ & $\begin{array}{l}1982 \\
\text { low }\end{array}$ & Company & $\begin{array}{l}\text { Close } \\
\text { previous } \\
\text { month }\end{array}$ & $\begin{array}{l}\text { Close } \\
29 \text { Oct. }\end{array}$ & Change \\
\hline 45 & $16^{1 / 8}$ & A.B. Fortia (Sweden) & $341 / 4$ & $391 / 2 *$ & $51 \frac{1}{4}$ \\
\hline 8 & 2 & Bio Logicals (Canada) & $21 / 2$ & $21 / 4$ & $-1 / 4$ \\
\hline 7 & $35 / 8$ & Bio-Response (USA) & $43 / 4$ & 5 & $1 / 4$ \\
\hline $14^{1 / 8}$ & $73 / 4$ & Cetus (USA) & $83 / 4$ & $93 / 4$ & 1 \\
\hline 11 & $61 / 8$ & Collaborative Research (USA) & $8^{5} / 8$ & $93 / 4$ & $1 / \frac{1}{8}$ \\
\hline $97 / 8$ & $53 / 4$ & Damon (USA) & $71 / 2$ & $91 / 8$ & $13 / 8$ \\
\hline 18 & $81 / 4$ & Enzo-Biochem (USA) & $14 \frac{1}{2}$ & 17 & $21 / 2$ \\
\hline 28 & $6 \%$ & Flow General (USA) & $10 \%$ & $131 / 4$ & $23 / 8$ \\
\hline $473 / 4$ & 26 & Genentech (USA) & $33 \frac{1}{4}$ & $473 / 4 *$ & $14^{1 / 2}$ \\
\hline $91 / 2$ & 7 & Genex (USA) & - & $91 / 4$ & - \\
\hline 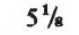 & $2 \frac{1}{4}$ & Genetic Systems (USA) & $31 / 4$ & $51 / 8$ & $\mathbf{1}$ \\
\hline $26^{1 / 4}$ & $95 / 8$ & Hybritech (USA) & $131 / 2$ & $201 / 2$ & 7 \\
\hline $113 / 4$ & 5 & Molecular Genetics (USA) & $10^{3 / 4}$ & $93 / 4$ & -1 \\
\hline 52 & $347 / 8$ & Novo Industri A/S (Den.) & 44 & $471 / 2$ & $31 \frac{1}{2}$ \\
\hline 17 & 8 & Monoclonal Antibodies (USA) & $81 / 4$ & $143 / 4$ & $6^{1 / 2}$ \\
\hline
\end{tabular}

The Nature Biotechnology Index for October, 1982, stands at 140.2, compared with 117.9 last month. Base is 100 as of 25 June 1982. Previous indexes appeared in Nature 12 August, p.599; 9 September, p.101; and 14 October, p.573. Close-of-month prices are the closing prices on the last Friday of each month. Where stocks are traded over the counter, the price quoted is the bid price. For stocks traded on the American and New York Stock Exchanges, the price quoted is the transaction price. Data from E.F. Hutton, Inc.

*High or low for this calendar year.

In response to readers' comments on the Biotechnology stock index, its composition has this month been changed. Thus Collagen Inc. - a company that does not use new biotechnology has been replaced by Genex, an important small company which made its first public stock offering after the close of the previous month's index.

This has been done by deleting Collagen's share of the market value of all the companies on 29 October and reallocating that share proportionally among the remaining 14 companies in the index. Then the total market value of Genex shares on that date (an estimated \$106 million) was added to the market values of the 14 companies and a new set of market shares calculated. This new set of divisors will be used in the calculation of future indexes.

In response to a further suggestion, there follows information on the trading symbols and, where appropriate, the stock exchanges on which the shares are traded. Most shares are traded over the counter (through brokers). Fortia (FOPHY); Bio Logicals (BIOLF); Bio-Reponse (BIOR); Cetus (CTUS); Collaborative Research (CRIC); Collagen (CGEN); Damon (DMN NYSE); Enzo-Biochemi (ENZO); Flow General (FGN); Genentech (GENE); Genetic Systems (GENS); Genex (GNEX); Hybritech (HYBR); Molecular Genetics (MOGN); Novo Industri A/S (NVO - NYSE); Monoclonal Antibodies (MABF). 